\title{
RISK ANALYSIS AND PRIORITIZATION IN WATER SUPPLY NETWORK MAINTENANCE WORKS THROUGH THE FAILURE MODES AND EFFECTS ANALYSIS: OCCUPATIONAL SAFETY FMEA APPLICATION
}

\section{Andre Luis de Oliveira Cavaignac \\ andreluiscavaignac@gmail.com CEUMA University, Brazil.}

Jhelison Gabriel Lima Uchoa jhelisong@hotmail.com CEUMA University, Brazil.

Heyglon Fábio Oliveira dos Santos

heyglon@live.de CEUMA University, Brazil.

\begin{abstract}
Goal: In this work, the application of FMEA (failure mode and effects analysis) in the execution of maintenance of water network in a medium size city in the state of Maranhão was approached. FMEA (failure mode and effects analysis) with occupational safety approach is applied in the execution of water supply network maintenance in a medium size city in the state of Maranhão. This work shows that FMEA is an effective tool for risk prioritization in work process. The FMEA application with use of index reference table can become faster than application without reference table - and thus spread the tool for risk analysis.
\end{abstract}

Design / Methodology / Approach: A photographic records was carried out in loco and the main risks to the workers were enumerated and based on the obtained data, a risk analysis was elaborated with the application of FMEA (Failure modes and effects analysis). Results: The maintenance services teams of the supply system are subject to a high risk of accidents caused mainly by the working conditions precariousness. It was observed that the services of manual excavations and the lack of use of PPE (helmet, gloves, pants suitable for flooded environments and etc.) have high risk index (RPN) and that the mismanagement added to the unsafe behavior were the main factors to accident occurrence in this type of work.

Limitations of the investigation: The study studied the reality found in a medium-sized city with precarious working conditions. Further studies can compare the work reality of other teams in cities of different sizes, with better working conditions. Other limitation of this work is the impossibility of work situation improvement and posterior tool application -a study with this magnitude is non-trivial and needs future research.

Practical implications: The great achievement of this work is to demonstrate that FMEA - a tool that is widely used in maintenance management and product engineering - is able to identify and prioritize risks based on its preliminary risk index obtained - contributing to reduce the difficulty of index choices previously cited in literature and disseminate the FMEA utilization for employee safety and occupational health. Such a tool has a great capacity for quantitative description of the risks, showing that the FMEA is very useful in the work safety sector for the organization of correction plans.

Originality / Value: The difficulties of using the tool mentioned in the available literature were minimized with the use of the reference table, showing that the use of FMEA can become faster and thus spread the tool for risk analysis.

Keywords: Occupational Safety; Water Source System; FMEA; Risk Analysis. 


\section{INTRODUCTION}

Civil construction was an area that has grown and developed in recent years. In 2017, the construction sector had a participation in the GDP (Gross Domestic Product) of approximately 15\% (Confederação Brasileira da Indústria da Construção, 2018) and is the sector that most employs people in the country (Mello and Amorim, 2009). However, it has an increasing number of workers in work accidents (Teixeira and Carvalho, 2005; Iriart et al., 2008). Construction workers responsible for maintenance of the water supply network are exposed to ergonomic risks and the incidence of musculoskeletal pain due to the practice of physical functions (Vitta et al., 2007)

According to data from the Ministry of Finance (Ministério da Fazenda, 2016), in 2016 there were 34,786 work departures registered with the Social Security, related to work accidents. However, many of these cases are not reported to Social Security due to the various nonconformities present in the employers' companies and the high level of informality in the sector (Santana and Oliveira, 2004; Teixeira and Carvalho, 2005)

Work accidents contribute to high corporate expenditures. The main causes of labor accident costs are employee retirement, first aid expenses, losses of equipment and damaged materials, and repair engineering (Costa et al., 2009). It is necessary to always verify the numerous risks associated with the tasks, with the purpose of eliminating failures or even accidents, in order to guarantee the established deadlines, cost, safety and quality of all those involved in the work performed (Araújo, 2002). To carry out the verification, the risk assessment must be present in all constructive steps (Cruz, 2002). For Saliba (2018), in order to minimize the risks to the maximum and preserve the employees' physical integrity, is necessary to use methods of risk management. It is worth noting that in order to obtain international quality certifications, risk analysis procedures are required (Zeng et al., 2010)

The FMEA (failure mode and effects analysis) is a tool that ranks the possible failure modes quantitatively, allowing risk prioritization and indicates which corrective measures should be performed (Stamatis, 2003). This tool was created in the mid-1940s by the American military in the post-war period (Pentti and Atte, 2002) and is currently used in several industrial, administrative and hospital sectors (Scipioni et al., 2002). However, the application of the FMEA in occupational safety is still less widespread and requires more in-depth studies on the subject (Cavaignac and Forte, 2018).

The FMEA lists the risks through a coefficient called the Risk Priority Number (RPN). This number is a result of the multiplication of three indexes: severity (S), occurrence (O) and detection (D), ranging from 1 to 10 , where the best situation has the lowest result and the worst situation has the highest result (Stamatis, 2003). The severity index indicates the severity of a consequence that may occur in the potential failure mode. The occurrence index is an estimate of the frequency or probability of occurring in failure mode. Already the detection is the difficulty of the fault being identified before the failure mode occurs (McDermott et al., 2012).

The indexes choice can generate doubts and cause difficulties in the tool application, avoiding the diffusion of its use in other areas besides reliability engineering (Laurenti et al., 2012). Previous work reported the indexes choice difficult in the application of FMEA in occupational safety for the first time, reinforce Laurenti et al. (2012) and (Cavaignac and Forte, 2018). In order to facilitate the use of FMEA in occupational safety, a recent study proposed a quick reference table, listing the possible situations found in the work environment with the $\mathrm{S}, \mathrm{O}$ and $\mathrm{D}$ indices (Cavaignac and Uchôa, 2018). This application field have a recent literature dedicated to occupational safety FMEA use and improvement, and shows that Cavaignac and Uchôa (2018) quick reference table turns the indexes choices easily, faster and non-subjective dependence (Jorge et al., 2019; Santos et al., 2019; Dias Junior and Cavaignac, 2019). Table 1 shows the relationship between the possible situations observed and the respective FMEA indexes.

The present work seeks to carry out the study of the labor situation of the employees of the maintenance services of the water supply network. The principal novelty of this work is the contribution of application development of occupational safety FMEA with quick reference table proposed by Cavaignac and Uchoa (2018), and added this, study a process that non-present on previous literature. Through on-site observation, situations of nonconformity with regulatory standards will be listed. Through the FMEA, the risks to which these employees are exposed will be prioritized and a corrective action plan will be proposed at the end.

\section{METODOLOGY}

This work was based on a case study on maintenance works of water supply networks in a medium-sized city in the State of Maranhão. Photographic records were taken in 03 (three) maintenance of the supply network and listed the situations of nonconformity followed by a brief discussion. Possible failures in the situations observed for the FMEA application were described, where possible failure modes, effects, detection methods, corrective actions and RPN were described. From this point, it was possible to make a comparison between the obtained results and to indicate which modes of failure need immediate corrective actions through the elaboration of a corrective action plan. Figure 1 shows the flowchart of the research execution steps. 
Brazilian Journal of Operations \& Production Management

Vol. 17, No. 1, e2020887, 2020

DOI: 10.14488/BJOPM.2020.006

Table 1. Relationship between the situations with the severity (S), occurrence (O) and detection (D) indexes.

\begin{tabular}{|c|c|c|c|c|c|}
\hline \multicolumn{2}{|r|}{ Severity (S) } & \multicolumn{2}{|r|}{ Occurrence (0) } & \multicolumn{2}{|r|}{ Detection (D) } \\
\hline Index & Consequence of failure & Index & Accident nature & Index & Detection methods \\
\hline 1 & No real impact & 6 & Impact suffered & 1 & Visual inspection \\
\hline 2 & Irrelevant trauma & 5 & Fall from height & 2 & \multirow{3}{*}{ Tactile test / manual test } \\
\hline 3 & Trauma requiring first aid & 5 & Impact against & 3 & \\
\hline 4 & $\begin{array}{l}\text { Temporary incapacity without } \\
\text { remoteness }\end{array}$ & 5 & Excessive or inappropriate effort & 4 & \\
\hline 5 & $\begin{array}{l}\text { Temporary incapacity with small } \\
\text { remoteness }\end{array}$ & 5 & Pressing or imprisonment & 5 & \multirow{3}{*}{$\begin{array}{l}\text { check-list/sequence of tests before } \\
\text { process }\end{array}$} \\
\hline 6 & $\begin{array}{l}\text { Temporary incapacity with large } \\
\text { remoteness }\end{array}$ & 5 & Fall from same level & 6 & \\
\hline 7 & Partial permanent disability & 4 & Noise exposure & 7 & \\
\hline 8 & Total permanent disability & 4 & Contact with hazardous substance & 8 & \multirow{2}{*}{$\begin{array}{l}\text { Instrumental inspection / } \\
\text { mechanical tests }\end{array}$} \\
\hline 9 & Death of involved in the process & 4 & Electric shock & 9 & \\
\hline 10 & Death of not involved in the process & 3 & Friction or abrasion & 10 & Lack of effective methods \\
\hline & & 3 & Temperature exposure & & \\
\hline
\end{tabular}

Source: Cavaignac and Uchôa (2018). Adapted

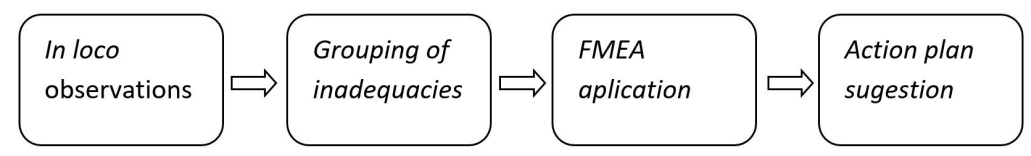

Figure 1. Research steps flowchart Source: Cavaignac and Forte (2018). Adapted

\section{INCONFORMITIES IN WATER SUPPLY NETWORK MAI-TENANCE}

With the photographic records in loco, several nonconformities to the regulatory norms were observed. It is important to stress that employees' observed attitudes, such as the lack of use of personal protective equipment, are extremely unsafe. Figures 2 to 6 below record the inadequacies during the maintenance process of the water supply network.

In Figures 2-6, it may be observer that employees do not make the correct use of PPE. According to NR 6, gloves have the purpose of protecting against piercing, cutting, chemical and biological agents, since the helmet has the purpose of protection against impacts that may occur in the skull region. For most employees, most PPE's do not have a certain comfort in their use, therefore, they discard their use on the grounds of such a situation. They also claim that they do not know how to use some PPE or also claim to forget it in their own homes or in the company closet. All these claims regarding the use of PPE's show a lack of concrete demand by the company for the use of PPE by employees.

Another point to note is where these employees meet. Such an area where the excavation was carried out for maintenance of networks, mostly are unhealthy places, thus compromising the health of the worker himself, due to

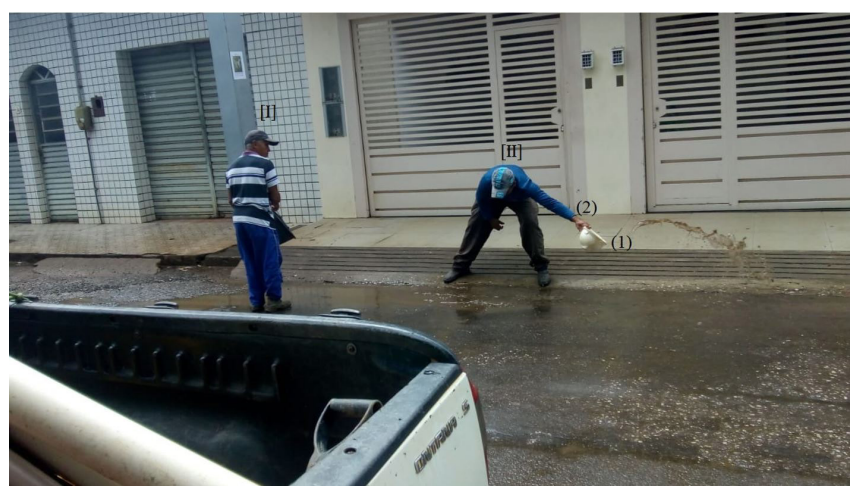

Figure 2 - Employees [I] and [II] with the wrong use of the PPE helmet (1) and absence of protective gloves (2). Source: the authors, 2019.

being exposed to chemical and biological agents. According to NR 18 , the places where there is excavation, must follow some criteria. Item 18.6 .7 says that excavations of more than $1.25 \mathrm{~m}$ (one meter and twenty-five centimeters), must contain stairs or ramps, place near the work stations, in order to allow in case of emergency. Item 18.6 .11 says that excavations carried out on public roads must contain warning signs and insulation barriers throughout its perimeter. Observing the images 2, 3, 4, 5 and 6, it is well known that such criteria of NR 18 have not been complied with, which can result in accidents. 


\section{FMEA APPLICATION ON WATER SUPPLY NETWORK MAINTENANCE}

For Puente et al. (2002), the FMEA has an important methodology to characterize the possible flaws, effects and processes to enumerate actions that can reduce or eliminate each risk. Due to the similarity between failures, the water supply maintenance process was divided into two subprocesses: pipe assembly, which consists of the activities performed during pipe maintenance and tool

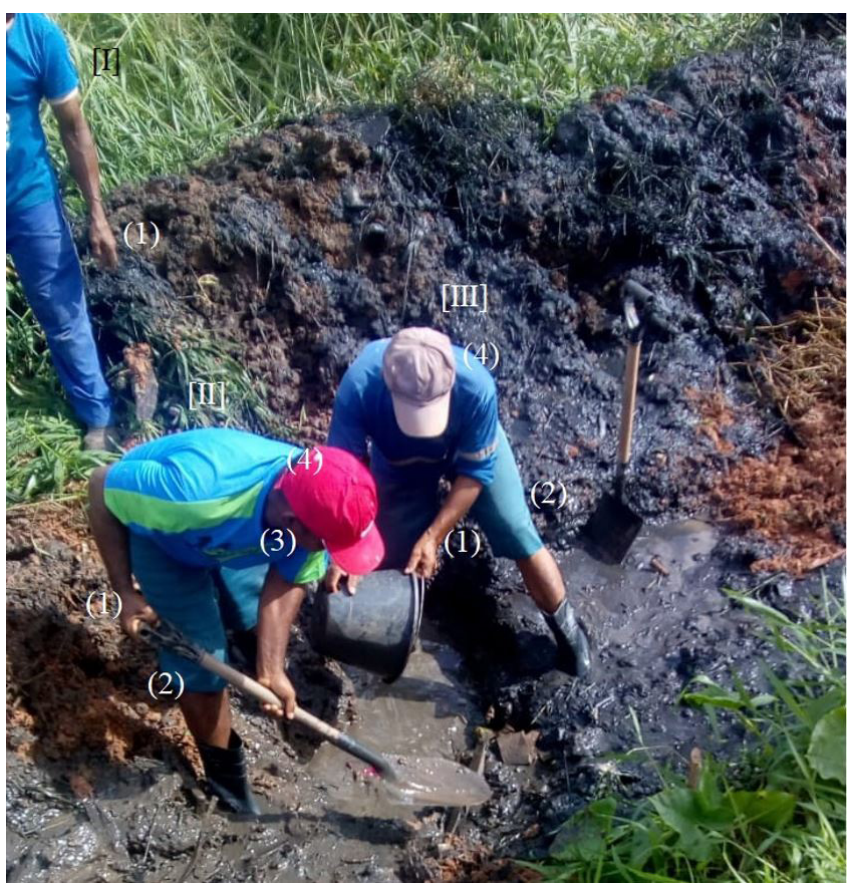

Figure 3 - Employees [I], [II] and [III] in a place of work with poor conditions and nonconformities. Observe the absence of gloves (1),

inappropriate work clothes (2) for the workplace, absence of protective masks (3) against toxic gases and absence of helmets (4) Source: the authors, 2019.

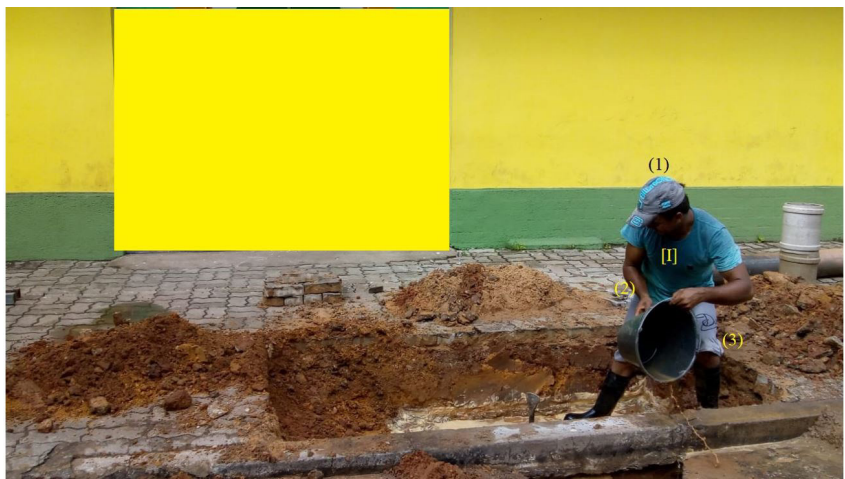

Figure 4 - Employees [I] in a work place close to traffic routes. The absence of a helmet (1) is observed; gloves (2); and garments not suitable for work (3). Source: the authors, 2019.

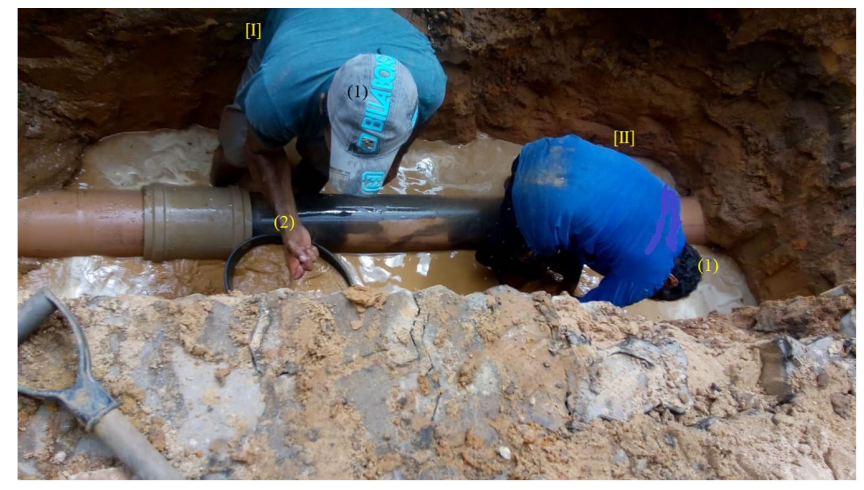

Figure 5 - Employees [I] and [II] working on excavations without shoring. The absence of helmets (1) is observed; inadequate clothing and protective gloves (2). Source: the authors, 2019.

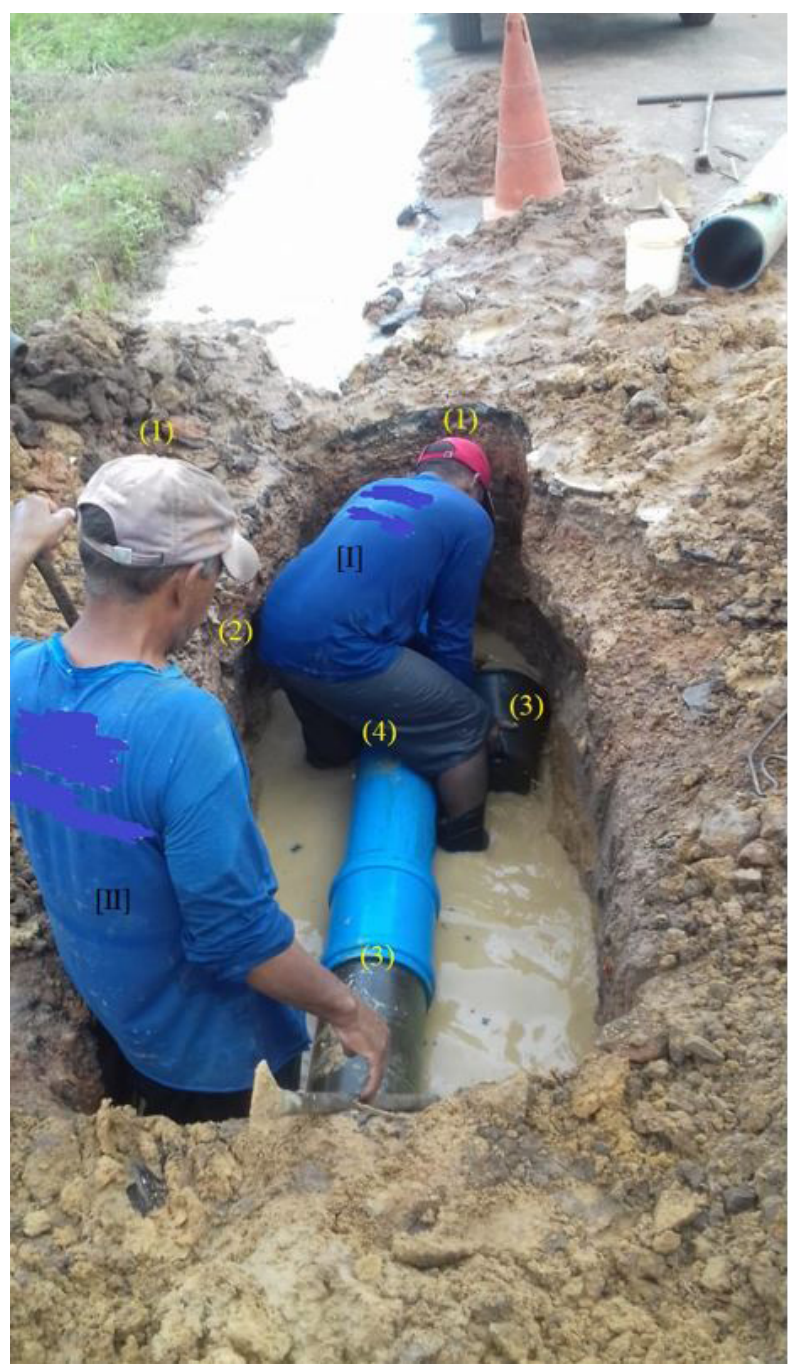

Figure 6 - Employees [I] and [II] in excavations without signaling and without shoring. The absence of helmets (1) is observed; absence of masks against toxic gases (2); absence of protective gloves (3); and garments not suitable for work (4) Source: the authors, 2019. 
use; and excavation work that considers the conditions of the work environment. The crashes were selected based on photographic records. The indices for occurrence (O), severity (S) and detection (D) were chosen from the analysis of the correlation of the situations observed in the case study with the indices proposed in the reference table elaborated by Cavaignac and Uchôa, (2018). Below, the failures will be analyzed and their correlations with the FMEA indices, as described in Table 2.

Mechanical shock during assembly may occur due to poor working environment conditions, either due to the lack of tool organization or the limited space available for work. This failure can result in the impact of objects against limbs - impact against, causing temporary incapacity without leaving the worker. Physical failure and / or failure of ergonomics occurs when exposing the worker to long hours of work and having irregular environments that require the employee to maintain incorrect posture to perform the activity, resulting in trauma that may require first aid on account of excessive and inadequate efforts. These two failures can be detected by tactile testing of tool use conditions, equipment weight, or avoiding inappropriate postures.

The absence or misuse of the helmet, as amply presented in the photographic records, may result in the impact of falling tools or supplies resulting in its long-term disability. This failure can be detected by the application of checklists before the activities start.

PPE such as gloves, mask against toxic gases and correct work suit protect workers who are performing maintenance of the supply pipes against possible chemical and biological agents. Failure to use these PPE, as noted in Figures 2-6, may result in contact of the skin with harmful substances resulting in irritating skin and respiratory tract development, in some cases causing the temporary incapacity of the employee. These failures are detected with checklist application at the beginning of the procedure, such as the service orders provided in the standart procedures. Table 3 below shows the prioritization of potential failure modes found in water supply network maintenance services.

Table 2. FMEA of water supply network maintenance process

\begin{tabular}{|c|c|c|c|c|c|c|c|c|c|}
\hline Subprocess & $\begin{array}{c}\text { Potential failure } \\
\text { mode }\end{array}$ & $\begin{array}{c}\text { Nature of } \\
\text { Occurrence }\end{array}$ & 0 & Failure effects & S & $\begin{array}{c}\text { Detection } \\
\text { methods }\end{array}$ & D & RPN & $\begin{array}{c}\text { Corrective } \\
\text { actions }\end{array}$ \\
\hline \multirow[t]{6}{*}{$\begin{array}{c}\text { Pipe } \\
\text { assembly }\end{array}$} & $\begin{array}{c}\text { Mechanical shock } \\
\text { during assembly }\end{array}$ & Impact against & 5 & $\begin{array}{c}\text { Temporary } \\
\text { incapacity without } \\
\text { remoteness }\end{array}$ & 4 & Tactile & 2 & 40 & $\begin{array}{c}\text { Workplace } \\
\text { inspection; Keep } \\
\text { organized and } \\
\text { unobstructed } \\
\text { environment }\end{array}$ \\
\hline & $\begin{array}{l}\text { Physical overload } \\
\text { and / or } \\
\text { ergonomics failure }\end{array}$ & $\begin{array}{c}\text { Excessive or } \\
\text { inappropriate } \\
\text { effort }\end{array}$ & 5 & $\begin{array}{c}\text { Trauma requiring } \\
\text { first aid }\end{array}$ & 3 & Tactile & 3 & 45 & $\begin{array}{l}\text { Breaks for rest; } \\
\text { Better tailor } \\
\text { tools and work } \\
\text { environment }\end{array}$ \\
\hline & $\begin{array}{c}\text { Absence or } \\
\text { improper use of } \\
\text { helmet }\end{array}$ & Impact suffered & 6 & $\begin{array}{c}\text { Temporary } \\
\text { incapacity with } \\
\text { large remoteness }\end{array}$ & 6 & Checklist & 5 & 180 & $\begin{array}{l}\text { PPE training; PPE } \\
\text { verification before } \\
\text { activities execution }\end{array}$ \\
\hline & Gloves absence & $\begin{array}{l}\text { Contact with } \\
\text { hazardous } \\
\text { substance }\end{array}$ & 4 & $\begin{array}{c}\text { Temporary } \\
\text { incapacity without } \\
\text { remoteness }\end{array}$ & 4 & Checklist & 5 & 80 & $\begin{array}{l}\text { PPE training; PPE } \\
\text { verification before } \\
\text { activities execution }\end{array}$ \\
\hline & $\begin{array}{l}\text { Toxic gas mask } \\
\text { absence }\end{array}$ & $\begin{array}{c}\text { Contact with } \\
\text { hazardous } \\
\text { substance }\end{array}$ & 4 & $\begin{array}{c}\text { Temporary } \\
\text { incapacity without } \\
\text { remoteness }\end{array}$ & 4 & Checklist & 6 & 96 & $\begin{array}{l}\text { PPE training; PPE } \\
\text { verification before } \\
\text { activities execution }\end{array}$ \\
\hline & $\begin{array}{l}\text { Inappropriate } \\
\text { Work Suit }\end{array}$ & $\begin{array}{c}\text { Contact with } \\
\text { hazardous } \\
\text { substance }\end{array}$ & 4 & $\begin{array}{c}\text { Temporary } \\
\text { incapacity without } \\
\text { remoteness }\end{array}$ & 4 & Checklist & 6 & 96 & $\begin{array}{l}\text { PPE training; PPE } \\
\text { verification before } \\
\text { activities execution }\end{array}$ \\
\hline \multirow[t]{3}{*}{$\begin{array}{c}\text { Work at } \\
\text { excavations }\end{array}$} & Signaling lack & $\begin{array}{l}\text { Pressing or } \\
\text { imprisonment }\end{array}$ & 5 & $\begin{array}{c}\text { Death of not } \\
\text { involved in the } \\
\text { process }\end{array}$ & 10 & $\begin{array}{c}\text { Visual } \\
\text { inspection }\end{array}$ & 1 & 50 & $\begin{array}{l}\text { visual signaling } \\
\text { assembly }\end{array}$ \\
\hline & Shoring lack & $\begin{array}{l}\text { Pressing or } \\
\text { imprisonment }\end{array}$ & 5 & $\begin{array}{l}\text { Death of involved } \\
\text { in the process }\end{array}$ & 9 & $\begin{array}{c}\text { Visual } \\
\text { inspection }\end{array}$ & 1 & 45 & $\begin{array}{l}\text { Ensure the safety } \\
\text { and stability adding } \\
\text { shoring excavation }\end{array}$ \\
\hline & $\begin{array}{l}\text { Lack of access } \\
\text { device } \\
\text { (ladder / ramp) }\end{array}$ & $\begin{array}{l}\text { Excessive or } \\
\text { inappropriate } \\
\text { effort }\end{array}$ & 5 & $\begin{array}{c}\text { Trauma requiring } \\
\text { first aid }\end{array}$ & 3 & $\begin{array}{c}\text { Visual } \\
\text { inspection }\end{array}$ & 1 & 15 & $\begin{array}{l}\text { ladders and access } \\
\text { ramps assembly }\end{array}$ \\
\hline
\end{tabular}


Table 3. Corrective action plan to prioritizing potential failure modes by RPN

\begin{tabular}{|c|c|c|c|}
\hline Priority & Potential failure mode & RPN & Corrective actions \\
\hline 1 은 & Absence or improper use of helmet & 180 & PPE training; PPE verification before activities execution \\
\hline 20 & Toxic gas mask absence & 96 & PPE training; PPE verification before activities execution \\
\hline 3은 & Inappropriate Work Suit & 96 & PPE training; PPE verification before activities execution \\
\hline 40 & Gloves lack & 80 & PPE training; PPE verification before activities execution \\
\hline 50 & Signaling lack & 50 & Visual signaling assembly \\
\hline 60 & Shoring lack & 45 & Ensure the safety and stability adding shoring excavation \\
\hline
\end{tabular}

Source: the authors, 2019.

The work performed in excavations was also in a precarious situation, being able to be observed failures with high severity for the worker. The excavations were without signalization, being able to result in the fall of people that are in the environs, resulting in the imprisonment in case of sliding, causing in its death. None of the excavations found adequate shoring. The landslide, which can be caused by the passage of vehicles or instability of the terrain, can result in the imprisonment of those who carry out the activity, resulting in their possible deaths. It is worth noting that despite the high severity, the resulting RPN is low, mainly due to the ease of detection of this fault - visual method with index 1 . The excavations also did not present any access device between the work surface and the ground, requiring the during their exit and entrance. This failure may result in the excessive or inadequate effort of the workers, resulting in the occurrence of trauma that may require first aid.

\section{CONCLUSION}

The workers safety is directly linked to the environment in which work occurs, as they are subject to risks. Through the on-site observations, it was possible to verify the most diverse occupational risks in which the employees are subject. From the qualitative enumeration of risks, the FMEA (failure mode and effects analysis) was used to quantify the possible causes and effects in which the workers are subject. It was verified that not using gloves is the most dangerous and had the highest result, followed by the absence of helmet use. Its worth to point that failure modes correlated with excavation process obtained small RPN - failure mode with visual detection - but have large severity index (9 and 10). This fact shows that excavation process need a special attention.

In addition to the study in question, the main function of this work is to use and disseminate the use of FMEA - a tool that is widely used in maintenance management and product engineering - for employee safety and occupational health. Such a tool has a great capacity for quantitative description of the risks, showing that the FMEA is very useful in the work safety sector for the organization of correction plans. The difficulties of using the tool mentioned in the available literature were minimized with the use of the reference table, showing that the use of FMEA can become faster and thus spread the tool for risk analysis. Compared to previous works, the principal novelty of this research is OS-FMEA application in a new process - Water supply newtork maintenance service - and obtain two principal achievments: (i) identifying and priorizing the risk that maintenance workers was exposed, to a correction action plan elaboration, and (ii) shows the OS-FMEA efficiency in a new process investigation.

\section{REFERENCES}

Araújo, N.M.C. (2002), Custos de implantação do PCMAT na ponta do lápis. Fundacentro, São Paulo.

Cavaignac, A.L.O. and Forte, L.L.N. (2018), “Utilização do FMEA para priorização de risco ocupacional: uma nova abordagem direcionada a construção civil", Brazilian Journal of Production Engineering, Vol. 4, n. 3, pp. 132-49, available at: http://periodicos.ufes.br/BJPE/article/view/v4n3_8/pdf, (accessed in 04 December 2019).

Cavaignac, A.L.O. and Uchoa, J.G.L. (2018), “Obtaining FMEA's indices for occupational safety in civil construction: a theoretical contribution", Brazilian Journal of Operations \& Production Management, Vol. 15, No. 4, pp. 558-65. http:// dx.doi.org/10.14488/BJOPM.2018.v15.n4.a9.

Confederação Brasileira da Indústria da Construção - CBIC (2018), "Banco de dados - CBIC", available at: http://www. cbicdados.com.br/menu/pib-e-investimento/pib-brasil-econstrucao-civil (accessed 10 January 2018).

Costa, J.F.S., Risicato, L.B. and Torres, C.A. (2009), "Metodologia multicritério na avaliação de custos na segurança do trabalho", Sistemas \& Gestão, Vol. 1, No. 2, pp. 104-15. http://dx.doi.org/10.7177/sg.2006.SGV1N2A1.

Cruz, P.M. (2012), Aplicação do 'Failure Mode and Effects Analysis (FMEA)' na demolição, movimento de terras e execução de estruturas em edifícios, Dissertação de Mestrado, Instituto politécnico do Porto, Porto. 
Dias Júnior, E.B., and Cavaignac, A.L.O. (2019), "Avaliação de riscos e falhas utilizando a ferramenta FMEA priorizando a NR-10 de serviços elétricos de baixa, média e alta tensão", Brazilian Journal of Production Engineering, Vol. 5, No. 3, pp. 214-25. http://dx.doi.org/10.0001/V05N03_004.

Iriart, J.A.B., Oliveira, R.P., Xavier, S.S. et al. (2008), "Representações do trabalho informal e dos riscos à saúde entre trabalhadoras domésticas e trabalhadores da construção civil", Ciência \& Saúde Coletiva, Vol. 13, pp. 165-74, available at: https://www.scielosp.org/scielo.php?pid=S1413$81232008000100021 \&$ script=sci_arttext\&tIng=es (accessed 4 December 2019).

Jorge, G.P.N., Sousa, M.J.A. and Cavaignac, A.L.O. (2019), "Priorização de risco em obra de médio porte por meio da utilização do FMEA: uma ferramenta de melhoria para segurança do trabalho em altura", Brazilian Journal of Production Engineering, Vol. 5, No. 3, pp. 35-53. http://dx.doi. org/10.0001/V05N03_003.

Laurenti, R., Villari, B.D. and Rozenfeld, H. (2012), "Problemas e melhorias do método FMEA: uma revisão sistemática da literatura", Pesquisa \& Desenvolvimento em Produção, Vol. 10, n. 1, pp. 59-70, available at: https://www. revista-ped.unifei.edu.br/documentos/V10N01/06-1211V10-N1-2012.pdf (accessed 4 December 2019).

McDermott, R., Mikulak, R.J. and Beauregard, M. (2009), The basics of FMEA, 2nd ed., CRC Press, Boca Raton, FL.

Mello, L.C.B.B. and Amorim, S.R.L. (2009), "O subsetor de edificações da construção civil no Brasil: uma análise comparativa em relação à União Europeia e aos Estados Unidos", Production Journal, Vol. 19, pp. 388-99, available at: https://www.redalyc.org/pdf/3967/396742036013.pdf (accessed 18 April 2019).

Ministério da Fazenda (2016), Anuário Estatístico da Previdência Social, Instituto Nacional do Seguro Social, Brasília, p. 917.

Pentti, H. and Atte, H. (2002), Failure mode and effects analysis of software - based automation systems, Radiation and Nuclear Safety Authority, Helsinki.

Puente, J., Pino, R., Priore P. et al. (2002), "A decision support system for applying failure mode and effects analysis", International Journal of Quality \& Reliability
Management, Vol. 19, No. 2, pp. 137-50. http://dx.doi. org/10.1108/02656710210413480.

Saliba, T.M. (2018), Curso Básico de Segurança e Higiene Ocupacional. LTR, São Paulo, p. 496.

Santana, V.S. and Oliveira, R.P. (2004), "Saúde e trabalho na construção civil em uma área urbana do Brasil", Caderno de Saúde Pública, Vol. 20, No. 3, pp. 797-811, available at: https://www.scielosp.org/ scielo.php?pid=S010211X2004000300017\&script $=$ sci arttext\&tIng=en (accessed 25 April 2019).

Santos, A.G.S., Nascimento Jorge, G.P. and Cavaignac, A.L.O. (2019), "FMEA como ferramenta de identificação dos riscos ao trabalhador da construção civil", Brazilian Journal of Production Engineering, Vol. 5, No. 3, pp. 19-34. http:// dx.doi.org/10.0001/V05N03_02.

Scipioni, A., Saccarola, G.A.C. and Arena, F.; (2002), "FMEA methodology design, implementation and integration with HACCP system in a food company", Food Control, Vol. 13, No. 8, pp. 495-501. http://dx.doi.org/10.1016/S09567135(02)00029-4.

Stamatis, D.H. (2003), Failure mode and effect analysis FMEA: from theory to execution, 2nd ed., ASQ Quality Press, Milwaukee.

Teixeira, L.P. and Carvalho, F.M.A. (2005), "A construção civil como instrumento de desenvolvimento da economia brasileira", Revista Paranaense de Desenvolvimento, No. 109, pp. 9-26, available at: https://dialnet.unirioja.es/descarga/ articulo/4813503.pdf, (accessed 25 April 2019).

Vitta, A., Zapater, A.R., Campos, R.S. et al. (2007), "Desconfortos musculoesqueléticos percebidos em trabalhadores de diferentes faixas etárias, gêneros e ocupações", Fisioterapia em Movimento, Vol. 20, No. 1, pp. 29-36, available at: https://periodicos.pucpr.br/ index.php/fisio/article/view/18831/18215, (accessed 221 April 2019).

Zeng, S.X., Tam, C.M. and Tam, V.W.Y. (2010), "Integrating safety, environmental and quality risks for project management using a FMEA Method", Inzinerine Ekonomika-Engineering Economics, Vol. 21, No. 1, pp. 44-52. available at: http:// inzeko.ktu.It/index.php/EE/article/view/11645/6327, (accessed 25 April 2019).

Received: 29 Aug 2019

Approved: 20 Sep 2019

How to cite: Cavaignac, A. L. O. and Uchoa, J. G. L. (2020). "Risk analysis and prioritization in water supply network maintenance works through the failure modes and effects analysis: Occupational safety FMEA application", Brazilian Journal of Operations \& Production Management, Vol. 17, No. 1. e2020887. https://doi.org/10.14488/BJOPM.2020.006 